\title{
Pemberdayaan Komunikasi Literasi dalam Berkarya Melalui Buku Format Digital Bagi Forum Wasilah 109
}

\author{
Robbikal Muntaha Meliala ${ }^{1^{*}}$ \\ ${ }^{1}$ Fakultas Komunikasi dan Bahasa, Universitas Bina Sarana Informatika, Jl. Kayu Jati V No.2 Rawamangun, Jakarta \\ Timur
}

*Email koresponden: bikal.muntaha@gmail.com

\section{ARTICLE INFO \\ Article history \\ Received: 24 Ags 2020 \\ Accepted: 25 Mar 2021 \\ Published: 23 Apr 2021}

\section{Kata kunci:}

Buku Digital

Forum Wasilah

Komunikasi Literasi

\section{Keyword: \\ Digital Book \\ Literacy \\ Communication \\ Wasilah Forum}

\begin{abstract}
A B S T R A K
Background: Forum Wasilah 109 merupakan organisasi alumni Rohani Islam SMAN 109 Jakarta yang mempunyai visi untuk memajukan potensi sumber daya manusia Indonesia untuk kesantunan dan keberadaban bangsa. Fakta lain menunjukan data dari UNESCO pada 2012, minat literasi masyarakat Indonesia masih rendah yaitu $0.001 \%$. Sementara, anggota Forum Wasilah 109 banyak yang berminat pada kegiatan literasi seperti menulis puisi, cerita pendek dan novel. Namun, mereka mempunyai keterbatasan akses untuk menerbitkan karyanya di wadah dan penerbit yang tepat. Beberapa diantara mereka juga belum mengetahui adanya buku format digital. Oleh karena itu, tim akademisi Universitas Bina Sarana Informatika membantu mitra ini dengan mengadakan webinar pemberdayaan komunikasi literasi pada buku format digital. 42 peserta mitra telah ikut berpartisipasi pada webinar tersebut. Metode: Metode pengumpulan data dilakukan dengan observasi, wawancara dan survey. Hasil: Kuesioner dibagikan pada peserta setelah webinar berlangsung. dan $97.6 \%$. Kesimpulan: peserta merasa puas pada kegiatan ini, serta $100 \%$ peserta tertarik untuk mengikuti agenda kegiatan pengabdian masyarakat Universitas Bina Sarana Informatika di masa depan.
\end{abstract}$$
\text { A B S T R A C T }
$$

Background: Forum of Wasilah 109 is an organization of Alumni Moslem Activist of 109 Senior High School Jakarta which have vision to encourage potency of Indonesian human resources toward politeness and civilization nation. Other fact has shown from UNESCO at 2012, literacy interest of Indonesian people is really low to $0.001 \%$. Meanwhile, many members of Forum Wasilah 109 have high interest in literacy activities such as writing poem, short story, poetry and novel. But, they are still have limited access to publish their letter in right place and right publisher. And among of them still do not know the existence of electronic book or digital books. Therefore, academician team from University of Bina Sarana Informatika supported this organization by conducting webinar of empowerment of literacy communication in digital format books. 42 participants have participated to this webinar. Methods: Method of data collecting are observation, interview and survey. Results: The Questionnaire was distributed to the participants after the webinar and $97.6 \%$. Conclusions: participant satisfied to this event and $100 \%$ have highly interest to participate in next event of community empowerment from University of Bina Sarana Informatika
\end{abstract}

\section{PENDAHULUAN}

Bangsa yang beradab adalah bangsa yang gemar membaca. Proses kegiatan membaca ini merupakan salah satu aspek dalam kegiatan literasi. Selama ini, masyarakat hanya mengetahui 
pengertian sempit dari literasi hanyalah kegiatan membaca saja. Padahal jika ditelisik lebih jauh, literasi adalah kegiatan dengan muatan aspek yang luas.

(Damayantie, 2018) menyatakan Literasi adalah yaitu kemampuan membaca, menulis dan berpikir kritis. Melalui literasi diharapkan tumbuh kesadaran kritis untuk mempelajari sesuatu yang baru atau mengasimilasikannya dengan pengetahuan sebelumnya. Dalam fungsinya, literasi mampu mempengaruhi pemikiran seseorang, menumbuhkan budaya kritis hingga melahirkan masyarakat yang cerdas dan memiliki daya saing.Sementara, membaca sendiri menurut (Harras, 2014) yaitu sebuah proses verbal yang tidak bergamitan dengan pikiran saja tetapi juga dengan aspek kemampuan komunikasi, menyimak, berbicara dan menulis. Jadi membaca itu agak berekuivalen dengan proses mendengar ke percakapan seseorang dan dengan rekonstruksi ide dari berbagai pola bunyi.

Maka dari itu, Literasi dapat diartikan sebagai kegiatan menulis, membaca, berbicara, mendengar dan berbudaya. Tak heran jika dunia literasi identik dengan cerminan kita sebagai masyarakat untuk berbahasa dan berbudaya. Cerminan bangsa untuk menjadi santun juga ditentukan dari minat literasi pada masyarakat di dalamnya. Bangsa akan kesulitan menjadi lebih beradab dan santun jika minat literasi pada masyarakatnya sendiri juga rendah dan tak ada perubahan peningkatan yang signifikan. Literasi pun berkaitan dengan komunikasi, karena dengan komunikasilah kita dapat mewariskan budaya atau warisan leluhur dan tanpa bahasa, mustahil bagi kita untuk berkomunikasi.

Menurut Menteri Pendidikan dan Kebudayaan yaitu Nadiem Makarim, minat baca di Indonesia masih rendah. Data United Nations Educational, Scientific and Cultural Organization (UNESCO) tahun 2012 menyebutkan bahwa minat baca di Indonesia hanya 0.001 persen (republika.co.id) dan menurut International Education Achievement (IEA) melaporkan bahwa kemampuan membaca anak sekolah dasar di Indonesia berada di urutan 38 dari 39 negara peserta studi (Meliala, Palupi, Septalastiani, 2018). Masalah minat baca di Indonesia memang telah banyak dibicarakan di koran, majalah, makalah dan artikel internet. Namun ironisnya, sampai saat ini belum ada peningkatan yang signifikan. Mahalnya harga buku di Indonesia diakui oleh Ketua Umum Ikatan Penerbit Indonesia (IKAPI) yaitu Rosidayati Rozalina, beliau mengatakan bahwa pajak kertas yang tinggi membuat penerbit tidak mau memberikan harga yang sesuai dengan biaya produksi mencetak buku. (www.ikapi.org). Selain itu, masih banyak faktor lain seperti tingkat kemiskinan dan infrastruktur yang sangat luas, penyebab tidak meratanya distribusi buku dan karya sastra di masyarakat Indonesia.

Mitra penulis kali ini adalah Forum Wasilah 109. Forum Wasilah 109 adalah komunitas Wadah Silaturrahim Muslim/ah Alumni SMAN 109 Jakarta. Wasilah 109 pertama kali dibentuk pada 17 Juli 1997 berkedudukan di wilayah Jakarta Selatan. Wasilah 109 terbuka bagi setiap muslimah alumni SMAN 109 Jakarta yang mengutamakan persaudaraan antar sesama muslim (ukhuwah islamiyah). Komunitas ini mempunyai visi untuk mewujudkan rumah alumni muslim yang beriman, bersahabat, dan berdedikasi demi hadirnya kebermanfaatan yang optimal bagi SMAN 109 Jakarta. Selain itu dengan misi organisasi yang terdiri dari penguatan alumni Muslim/ah, optimalnya syiar Islam, kaderisasi dakwah dan keuangan yang settle, berusaha terus menciptakan program kerja unggulan mereka yang terdiri dari MIND Academy (Syiar dan Pembinaan), Mentoring dan Keputrian (Pembinaan), Character Building (Pembinaan), Muhasabah Siswa/I Kelas 12 (Syiar dan Pembinaan), Penuansaan Ramadhan (Syiar), Silaturahmi Alumni Rohis dan Guru (Alumni Relations) dan Galang Donasi (Alumni Relations).

Dalam menyukseskan program kerja unggulan tersebut, Wasilah 109 juga membuka pintu kerjasama dengan pihak eksternal yang sepemikiran untuk membangun kualitas bangsa. Pintu 
kerjasama ini dibuka oleh organisasi ini melalui akun media sosial resmi di instagram @wasilah109 dan juga di line pada akun @560qkcpp. Melihat latar belakang ini, tim dosen program studi penyiaran berniat baik untuk dapat menjalin kerjasama dengan wasilah 109 dengan berpartisipasi dalam menyukseskan program kerja unggulannya pada fokus menggalang dana untuk kebermanfaatan umat dan pembinaan character building khususnya edukasi komunikasi literasi.

Banyak anggota organisasi dalam komunitas Wasilah 109 ini yang mempunyai hobi menulis dan membaca. Selain itu, diantaranya ada yang berminat untuk menerbitkan karya tulisnya namun kebingungan dalam mengakses saluran untuk menerbitkannya. Ada juga di antara mereka yang berminat untuk menulis karya sastra namun bingung untuk memulainya dari mana dan bagaimana menulis yang baik dan benar. Wawancara pendahuluan yang dilakukan penulis kepada perwakilan wasilah 109 pada 2 Mei 2020 yaitu Laila Zahira Fatin, mendapatkan kesimpulan bahwa mereka memerlukan pembinaan dan diskusi praktis untuk mengatasi permasalahan edukasi literasi tersebut. Pembinaan itu juga dapat diperoleh melalui bantuan pihak eksternal, salah satunya dari Universitas Bina Sarana Informatika (UBSI).

Berawal dari hal itu, maka tim dosen program studi penyiaran Universitas Bina Sarana Informatika (UBSI) akan membantu komunitas Wasilah 109 dalam mengadakan kampanye edukasi literasi. Kampanye edukasi literasi itu bertajuk "Pemberdayaan Komunikasi Literasi Dalam Berkarya Melalui Buku Format Digital". Keadaan era industri revolusi 4.0 membawa perubahan selera masyarakat kini pada kemapanan dalam memanfaatkan digitalisasi.

Menurut (Shwab, 2016), Globalisasi telah memasuki era baru yang bernama Revolusi Industri 4.0. Klaus melalui The Fourth Industrial Revolution menyatakan bahwa dunia telah mengalami empat tahapan revolusi, yaitu: 1) Revolusi Industri 1.0 terjadi pada abad ke 18 melalui penemuan mesin uap, sehingga memungkinkan barang dapat diproduksi secara masal, 2) Revolusi Industri 2.0 terjadi pada abad ke 19-20 melalui penggunaan listrik yang membuat biaya produksi menjadi murah, 3) Revolusi Industri 3.0 terjadi pada sekitar tahun 1970an melalui penggunaan komputerisasi, dan 4) Revolusi Industri 4.0 sendiri terjadi pada sekitar tahun 2010an melalui rekayasa intelegensia dan internet of thing sebagai tulang punggung pergerakan dan konektivitas manusia dan mesin.

Buku konvensional dahulu yang mungkin hanya dapat ditemukan di toko buku konvensional dan perpustakaan, kini terdiversifikasi beralih pada buku format digital atau e-book atas azas efisiensi dan efektivitas. Hal ini juga menjadi pemicu dan tujuan bagi penulis untuk memperkenalkan format buku digital dan akses penerbit terpercaya dalam memproduksi karya tulis digital yang dimiliki masyarakat

\section{MASALAH}

Permasalahan yang ditemukan pada mitra pengabdian masyarakat adalah :

1. Banyak Anggota Forum Wasilah 109 yang merupakan alumni dari SMAN 109 Jakarta, mempunyai hobi menulis dan menyimpan bakat terpendam untuk menjadi sastrawan, namun keterbatasan akses dalam menerbitkan karyanya di wadah dan penerbit yang tepat.

2. Pada sisi lain, beberapa anggota Forum Wasilah 109 masih memiliki keterbatasan pengetahuan tentang buku format digital dan bagaimana dapat mengaksesnya, berkarya serta menulis melalui buku format digital tersebut. 


\section{METODE PELAKSANAAN}

Metode yang dilakukan dalam kegiatan pengabdian masyarakat ini adalah sistem webinar atau seminar dalam jaringan internet. Wabah pandemi covid 19 membatasi proses edukasi dapat dilakukan secara langsung bertemu fisik dan tatap muka. Oleh karena itu, proses pembelajaran jarak jauh atau seminar dalam jaringan internet merupakan solusi yang dapat dipilih panitia pengabdian masyarakat untuk mengeksekusi kegiatan ini.

1. Tahap persiapan materi yang akan disampaikan oleh tutor. Kegiatan observasi dan studi kepustakaan tentunya dilakukan untuk memproduksi modul terbaik bagi peserta. Tutor dalam kegiatan ini adalah Drs. Priatna, M.Si, MM.

2. Tahap selanjutnya adalah pembekalan materi dari tutor yang disampaikan kepada peserta melalui seminar dalam jaringan internet pada link Google Meet (https://meet.google.com/qqjhzmg-quk) .

3. Tahap tanya jawab antara narasumber atau tutor dengan peserta seminar dalam jaringan internet.

4. Tahap pembagian kuesioner kepada peserta seminar dalam jaringan melalui google form untuk mengevaluasi keberhasilan kegiatan pengabdian masyarakat.

5. Tahap bimbingan antara tutor dengan peserta setelah webinar, melalui jaringan pribadi email ke email tentang teknik penulisan dan prosedur penerbitan karya dalam bentuk buku format digital.

\section{HASIL DAN PEMBAHASAN}

Pengabdian masyarakat yang dilakukan dengan seminar dalam jaringan internet ini, dilakukan pada hari Minggu, 14 Juni 2020. Acara dimulai dari pukul 10.00 WIB s.d 12.00 WIB. Acara ini diikuti oleh 42 peserta, dimana peserta sebelumnya diwajibkan untuk melakukan registrasi via media sosial dan pengisian google form terlebih dahulu, untuk mendapatkan link google meet pada hari Minggu, 14 Juni 2020. Acara ini diketuai oleh Robbikal Muntaha Meliala, S.Sos, M.I.Kom dan didukung oleh Tutor Utama atau Narasumber yaitu Drs. Priatna, M.Si, MM, serta dibantu oleh tim tutor lain yang terdiri dari Romi Syahril, S.Sos, MM, Azhar Hutomo, S.Sos, M.Si, Marlina Rahmi Shinta, SE, MM, A. Rafiq, S.Sos.I, MM dan salah satu perwakilan mahasiswa prodi penyiaran UBSI yaitu Adnan Aditiyana.

Salah satu peserta webinar yang merupakan anggota Wasilah 109 dan berstatus sebagai mahasiswi Sastra Arab Universitas Indonesia yaitu Laila Zahira Fatin menyatakan kegiatan ini sangat membantu untuk memberdayakan kemampuan menulisnya. Setelah webinar berlangsung, Laila dapat bimbingan secara online melalui surat elektronik (email) dengan narasumber yaitu Drs. Priatna, MM, M.Si dan tutor lainnya yang merupakan dosen Prodi Penyiaran Universitas Bina Sarana Informatika (UBSI). Bimbingan secara daring (dalam jaringan internet atau online) itu mendorong Laila untuk berhasil menerbitkan tulisan artikelnya di link berikut : https://ksm.ui.ac.id/putri-jasmine-simbol-narasi-perjuangan-perempuan-di-timur-tengah/ .

Kini, Laila juga merupakan aktivis Universitas Indonesia yang tergabung pada KSM (Kelompok Studi Mahasiswa) Eka Prasetya UI. Laila berhasil menjadi anggota KSM Eka Prasetya UI juga setelah melalui serangkaian proses yang ketat, salah satunya adalah menulis artikel semi ilmiah maupun ilmiah. Laila menyatakan kemampuan menulisnya semakin terasah berkat bimbingan dan webinar pemberdayaan komunikasi literasi ini yang diadakan oleh Dosen Program Studi Penyiaran Universitas Bina Sarana Informatika (UBSI). Selain itu, Laila berencana untuk menerbitkan buku format digitalnya dengan dibantu Drs. Priatna, M.Si, MM pada penerbit Tempo Media Grup pada Awal April 2021. Wawancara yang dilakukan penulis ini dapat menjadi 
salah satu jawaban atau bukti kontribusi dalam menyelesaikan permasalahan yang diangkat dalam pengabdian masyarakat.

Berikut adalah susunan acara yang dilakukan tim panitia dosen prodi penyiaran Universitas Bina Sarana Informatika (UBSI) pada seminar tersebut :

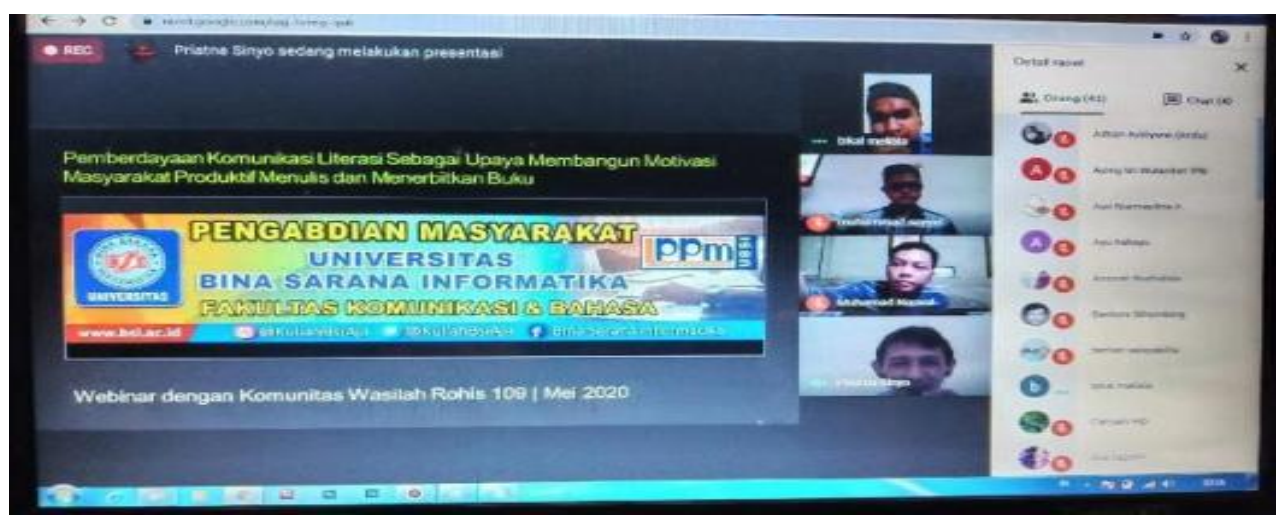

Gambar 1. Foto saat Tutor yaitu Drs. Priatna, M.Si, MM memulai pemaparan materi

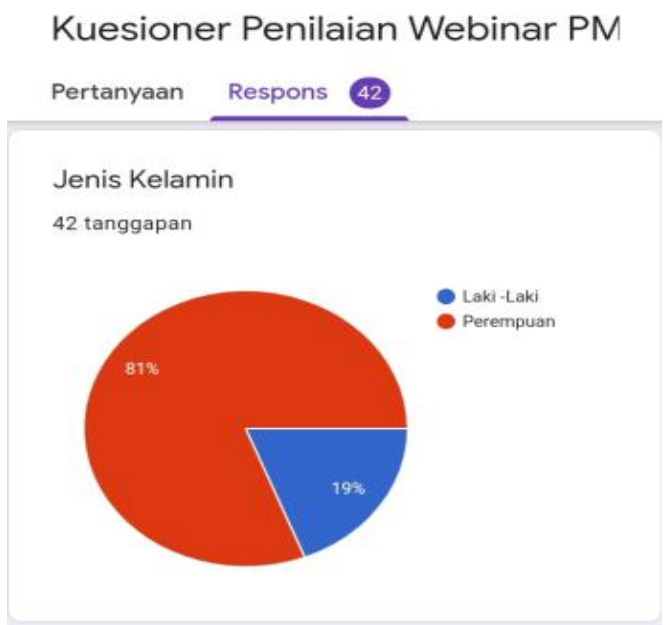

Gambar 2. Diagram Sebaran Jenis Kelamin Peserta Mitra Forum Wasilah 109 yang mengikuti Webinar.

Pada diagram dapat diketahui bahwa peserta mitra terdiri atas 42 orang, dimana 19\% berjenis kelamin laki-laki dan perempuan sebanyak $81 \%$.

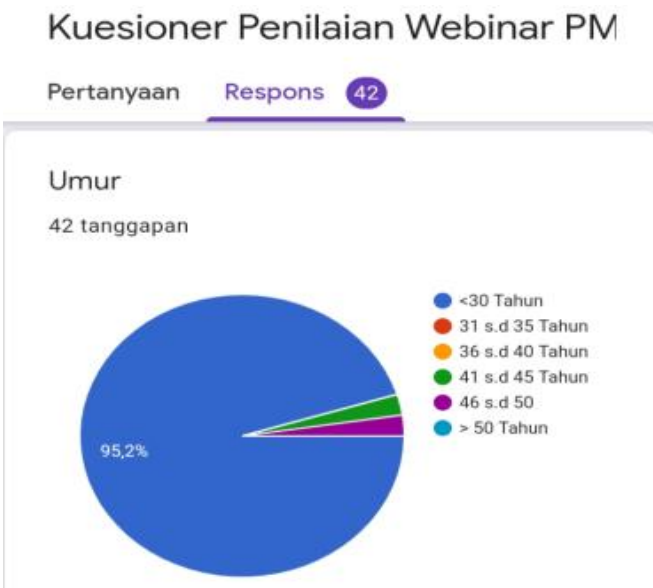

Gambar 3. Diagram Sebaran Umur Peserta Mitra Forum Wasilah 109 yang mengikuti Webinar. 
Pada diagram dapat diketahui bahwa peserta mitra didominasi $95.2 \%$ berusia dibawah 30 tahun,

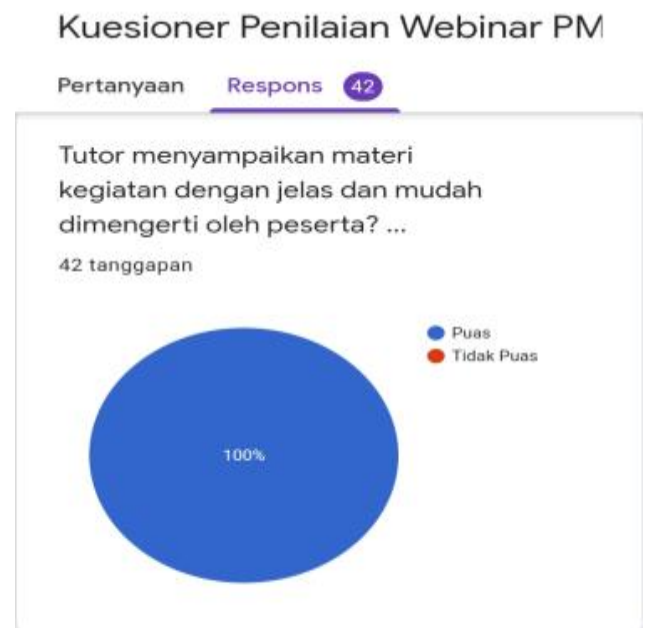

Gambar 4. Diagram tingkat kepuasan peserta mitra Forum Wasilah 109 terhadap penjelasan tutor.

Pada diagram dapat diketahui bahwa 100\% peserta mitra menyatakan personil atau anggota panitia berkontribusi sesuai dengan kebutuhan

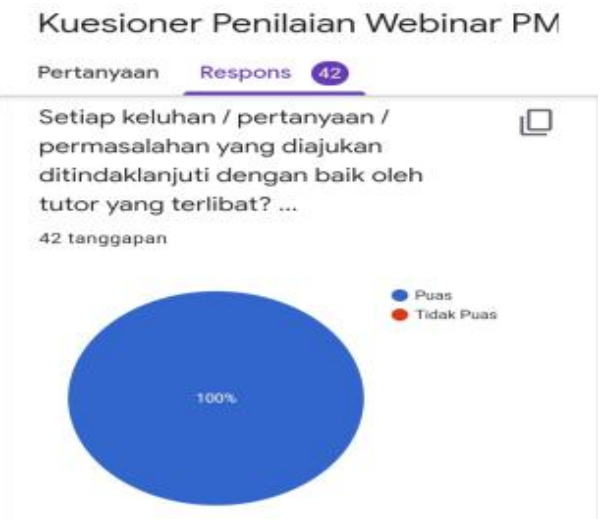

Gambar 5. Diagram tingkat kepuasan peserta mitra terhadap tindaklanjut atau jawaban tutor.

Pada diagram dapat diketahui bahwa peserta mitra menyatakan 100\% tutor aktif dalam menindaklanjuti pertanyaan atau permasalahan.

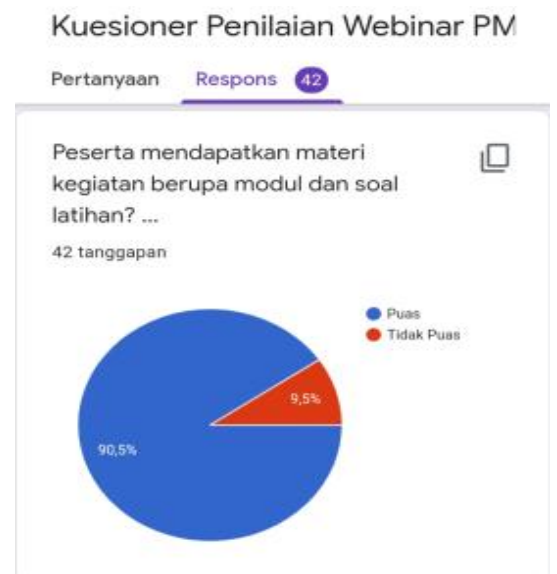

Gambar 6. Diagram sebaran jumlah peserta mitra yang mendapat modul atau materi webinar. 
Pada diagram dapat diketahui peserta mitra sejumlah $90.5 \%$ mendapatkan modul dari webinar.

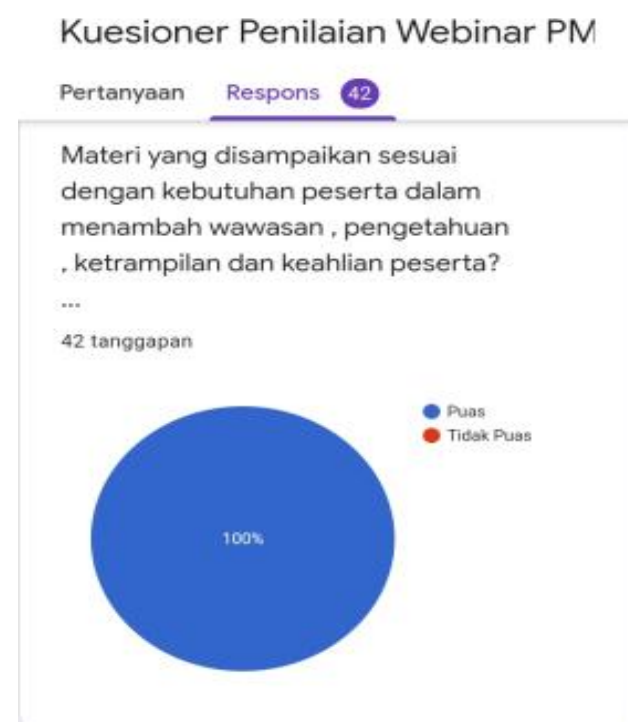

Gambar 7. Diagram tingkat kepuasan peserta mitra terhadap penambahan pengetahuan dari materi webinar.

Pada diagram dapat diketahui peserta mitra sejumlah 100\% puas dengan materi yang disampaikan untuk menambah wawasan, pengetahuan, keterampilan dan keahlian.

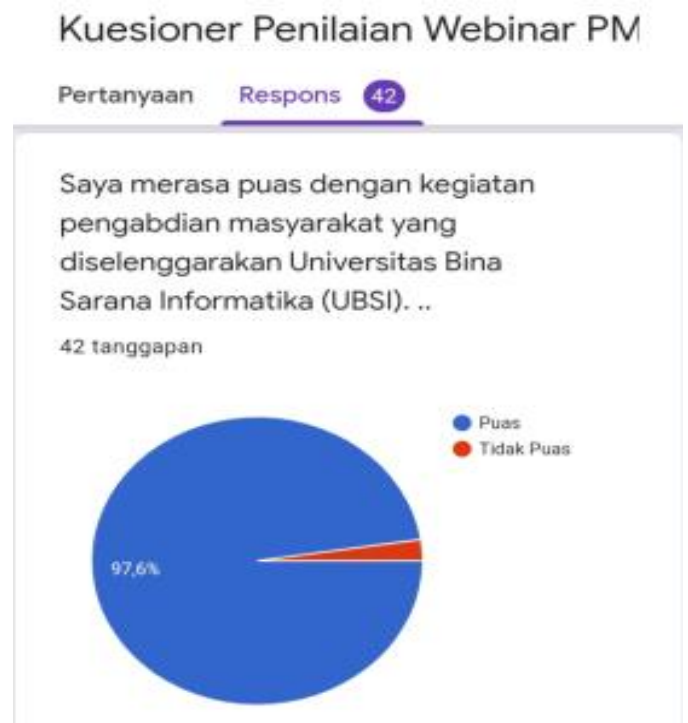

Gambar 8. Diagram tingkat kepuasan peserta mitra terhadap keseluruhan kegiatan webinar.

Pada diagram dapat diketahui bahwa peserta mitra sejumlah 97.6\% merasa puas dengan kegiatan pengabdian masyarakat ini. 


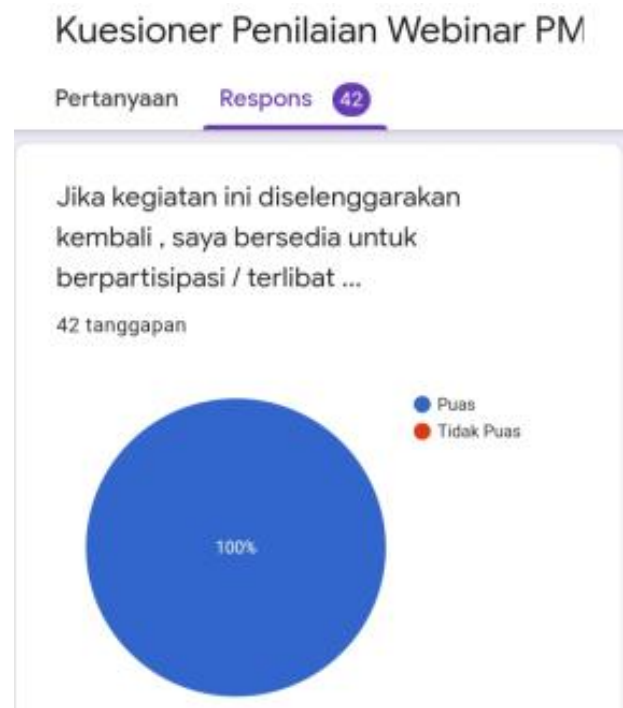

Gambar 9. Diagram tingkat ketertarikan peserta mitra untuk mengikuti agenda acara pengabdian masyarakat di masa depan.

Pada diagram dapat diketahui peserta mitra sejumlah $100 \%$ tertarik untuk mengikuti kegiatan pengabdian masyarakat selanjutnya

\section{Komunikasi Literasi}

Komunikasi dapat dibedakan atas komunikasi verbal dan komunikasi nonverbal. Komunikasi verbal lebih banyak menggunakan simbol-simbol bahasa sedangkan nonverbal kebalikannya. Hasil penelitian menunjukkan bahwa $80 \%$ dalam komunikasi didominasi oleh faktor nonverbal (Ramadanty, 2014). Hal ini dikarenakan keterbatasan kata dalam menyampaikan maksud, makna kata yang ambigu, serta adanya penafsiran. Oleh karena itu, keberhasilan komunikasi verbal sangat dipengaruhi oleh faktor: inteligensi, budaya, pengetahuan, kepribadian, biologis, dan pengalaman (Mulyaningsih, 2019).

Literasi merupakan kemampuan yang dimiliki individu dalam membaca teks maupun konteks serta menggunakannya dalam kehidupan sehari-hari (Syahid, 2017). Literasi juga disinonimkan dengan melek huruf yang artinya, terampil secara kognitif, membaca, dan menulis, baik berupa teks maupun konteks. Literasi juga dimaknai sebagai praktik dan interaksi sosial yang berhubungan dengan pengetahuan, bahasa, dan budaya (Teguh, 2017). Pernyataan di atas menunjukkan bahwa komunikasi dan literasi tak dapat dipisahkan satu sama lain. Budaya literasi perlu dikembangkan dengan pendekatan komunikasi yang dapat dinamakan dengan sosialisasi atau kampanye. menrumuskan definisi kampanye sebagai serangkaian kegiatan komunikasi yang terorganisasi dengan tujuan untuk menciptakan dampak tertentu terhadap sebagaian besar khalayak sasaran secara berkelanjutan dalam periode waktu tertentu (Mulyana, I. et al., 2019).

Menurut (Ardiana \& Damayanti M. N., 2016), kampanye merupakan sebagai sebuah proses untuk mengkomunikasikan pesan pesan yang berisi tentang masalah-masalah sosial kemasyarakatan dan juga bersifat non komersil. Tujuan umum dari kampanye sosial sendiri adalah untuk menumbuhkan kesadaran masyarakat akan gejala sosial yang sedang terjadi.

Penulis menyimpulkan komunikasi literasi adalah kegiatan menyampaikan pesan untuk mempengaruhi penerima pesan agar memberdayakan kemampuan membaca, menulis, mendengar, berbahasa dan berbudaya-nya sebagai salah satu bentuk keperluan sebagai manusia yang berkembang dan beradab. Komunikasi literasi ini adalah komunikasi yang ditujukan sebagai 
upaya sosialisasi dan kampanye agar masyarakat berpartisipasi pada pembangunan bangsa dengan memajukan minat dan produksi literasi dalam kehidupan sehari-hari.

\section{Buku Format Digital (E-Book)}

Revolusi Industri 4.0 secara fundamental mengakibatkan berubahnya cara manusia berpikir, hidup, dan berhubungan satu dengan yang lain. Era ini akan mendisrupsi berbagai aktivitas manusia dalam berbagai bidang, tidak hanya dalam bidang teknologi saja, namun juga bidang yang lain seperti ekonomi, sosial, dan politik. (Muhson, 2010). Salah satu aspek yang dirasakan akibat revolusi industri 4.0 ini pada dunia literasi adalah kehadiran buku format digital. Menurut (Landoni, 2003), ebook adalah sebuah bentuk digital, sebuah media di mana informasi diorganisasikan dan terstruktur sehingga dapat dipresentasikan ke pembaca. Ebook juga didefinisikan sebagai publikasi buku dalam bentuk digital, terdiri dari teks, gambar, atau keduanya, dan mudah dibaca pada komputer atau peralatan elektronik lainnya(Gardiner et al., 2010). (Fasimpaur, 2004) mengungkapkan bahwa siswa menganggap buku digital sebagai "media baru dan unik", dan hasilnya siswa lebih sering membaca ketika mendapatkan akses buku digital. Studi yang dilakukan oleh(Doty et al., 2001) menyatakan bahwa membaca teks pada layar komputer jauh lebih efektif dibandingkan buku teks cetak.

Penulis menyimpulkan buku format digital adalah transformasi bentuk buku konvensional atau buku teks cetak ke dalam bentuk baru dan unik, dimana dapat disimpan dalam format PDF pada media elektronik seperti komputer, gawai sehingga mudah dibawa, praktis dan dapat diakses dengan bantuan koneksi internet atau piranti teknologi lainnya. Kehadiran buku format digital ini juga disukai oleh pelajar atau siswa dan dianggap lebih efektif.

\section{KESIMPULAN}

Penulis dapat menyimpulkan bahwa Pengabdian masyarakat dalam bentuk webinar ini mendapat antusias tinggi bagi peserta mitra Forum Wasilah 109, dimana hasil evaluasi menunjukkan $97.6 \%$, peserta puas dengan pemaparan materi dari narasumber utama. Selain itu, $100 \%$ peserta menyatakan tertarik untuk mengikuti pengabdian masyarakat selanjutnya yang akan dibuat oleh tim panitia dosen prodi penyiaran Universitas Bina Sarana Informatika (UBSI). Beberapa peserta webinar dapat bimbingan langsung secara online melalui surat elektronik (email) dengan Narasumber Drs. Priatna, M.Si, MM dan tutor lainnya yang merupakan dosen Program Studi Penyiaran UBSI. Salah satu peserta diantaranya adalah Laila Zahira Fatin yang merupakan Mahasiswi Sastra Arab Universitas Indonesia (UI) berhasil menjadi anggota Kelompok Studi Mahasiswa (KSM) Eka Prasetya UI dan berhasil menerbitkan artikel ilmiahnya di link https://ksm.ui.ac.id/putri-jasmine-simbol-narasi-perjuangan-perempuan-di-timur-tengah/. Selain itu, Laila dengan dibantu Drs Priatna, M.Si, MM dan tutor Dosen UBSI lainnya berencana menerbitkan buku format digitalnya pada penerbit Tempo Media Group pada April 2021.

\section{UCAPAN TERIMA KASIH}

Penulis berterima kasih sekali terutama kepada Laila Zahira Fatin, Rifda dan Muhamad Nauval yang bersedia menjembatani komunikasi antara pihak Forum Wasilah 109 dengan Tim Panitia Pengabdian Masyarakat Dosen Program Studi Penyiaran, Universitas Bina Sarana Informatika (UBSI) demi suksesnya webinar ini. 


\section{DAFTAR PUSTAKA}

Ardiana, N. P. L., \& Damayanti M. N., \& M. C. (2016). Perancangan Kampanye Sosial tentang Pemahaman Eksistensi Keragaman Lintas Etnis di Semarang. Jurnal DKV Adiwarna, 1(8), 1-11.

Damayantie, A. (2018). Literasi Dari Era Ke Era. Jurnal Pendidikan, 1(1), 1-10.

Doty, D., Popplewell, S., \& Byers, G. (2001). Interactive CD-ROM storybooks and young readers' reading comprehension. Journal of Research on Computing in Education, 33(4), 374-384.

Fasimpaur, K. (2004). E-books in schools: Check out the reasons why e-books are gaining popularity in K-12 schools. Journal of Media \& Methods, 40(5), 12.

Gardiner, Eileen, \& Musto., R. G. (2010). "The Electronic Book." In The Oxford Companion to the Book, edited by H.R. Woudhuysen and Michael F. Suarez. Oxford University Press.

Harras, K. A. (2014). Hakikat dan Proses Membaca. Modul Universitas Terbuka. Universitas terbuka.

Landoni, M. (2003). "The Visual Book System: A Study of the Use of Visual Rhetoric in the Design of Electronic Books". PhD thesis. University of Strathclyde.

Muhson, A. (2010). Pengembangan Media Pembelajaran Berbasis Teknologi Informasi. Jurnal Pendidikan Akuntansi Indonesia, 8(2). https://doi.org/10.21831/jpai.v8i2.949

Mulyana, I., K., M., Putra, A. P., K., \& M., Suriansyah, M. I., \& Kom, M. (2019). Buku Ajar Desain Grafis Dan Multimedia (Vol. 1). Flash.

Mulyaningsih, I. (2019). Peran Literasi Komunikasi Pada Suatu Komunitas. Jurnal Pendidikan Dan Pengajaran Bahasa Indonesia, 2(1), 137-142.

Ramadanty, S. (2014). Penggunaan Komunikasi Fatis dalam Pengelolaan Hubungan di Tempat Kerja. Jurnal Ilmu Komunikasi, 5(1), 1-12.

Shwab, K. (2016). The Fourth Industrial Revolution. Crown Business.

Syahid, A. S. (2017). Hati-hati Mengartikan, Gerakan Literasi Bukan Sekadar Gerakan Baca dan Tulis. Kompas.

Teguh, M. (2017). Aktualisasi Kurikulum 2013 di Sekolah Dasar melalui Gerakan Literasi Sekolah untuk Menyiapkan Generasi Unggul dan Berbudi Pekerti" Dalam Prosiding Seminar Nasional. 